\title{
Addressing the Jewish Question with Humor: Poverty and Unproductivity in the Dutch Purim Productions (ca. 1800)
}

\author{
TSILA RÄDECKER@ \\ Faculty of Theology and Religious Studies, University of Groningen, Groningen, \\ The Netherlands \\ E-mail: tsilaradecker@hotmail.com
}

\begin{abstract}
This essay investigates the appearance in the Dutch Purim productions of such contemporary political issues as the poverty and the unproductivity of the Ashkenazi Jews. At the end of the eighteenth century, pejorative images of the Jew and maskilic reform, as well as enlightened ideals, interacted within these writings. As a result, the focus of the Purim productions shifted from absurd humor to the hardships of Jewish life. This essay analyzes how maskilim employed the Ashkenazi Purim productions to cope with and address the "Jewish Question." As such, it demonstrates that humor became an ideological motor for Jewish cultural change.
\end{abstract}

Keywords Amsterdam $\cdot$ Ashkenazi community $\cdot$ Purim productions $\cdot$ Maskilim $\cdot$ Humor

"With the sun I discussed the four elements of life: hunger, thirst, bad housing, and the lack of peat in the winter." In this intentionally comic anecdote, the author of A naye Purim lukh [A new Purim calendar] criticizes the deplorable state of the Dutch Jews. Unemployment, poverty, and a lack of education troubled this group at the turn of the nineteenth century. Numerous enlightened writings offered solutions to improve their status, ranging from the abolishment of religious rituals to the reformation of the Jewish education system. For instance, the German Christian Wilhelm von Dohm (1781-83) published the pamphlet Über die bürgerliche Verbesserung der Juden [On the civil improvement of the Jews] wherein he proposed that, if they wanted to be part of society and be eligible for citizenship, the Jews should transform their religion. A similar critique was made in an essay published in De Koopman (1770), a popular Dutch enlightened journal, wherein it was suggested that the Sabbath be moved to Sunday, thereby solving the Jews' poverty problem. ${ }^{2}$ Many held the Ashkenazi way of life (partly) responsible for both the Jews' poverty and their legal inequality. The connection between Judaism and poverty also appears in the late eighteenth- and

\footnotetext{
${ }^{1}$ A naye Purim lukh [A new Purim calendar], fol. 1, EH 20B 67, Ets Haim Library, Amsterdam. The author also speaks of the nine elements of life. See ibid., fol. 10. Unless otherwise noted, all translations are my own.

2"Een Hollandsch-joodsch hervormingsplan," De Koopman of Weekelijksche bij-dragen ten opbouw van Nêerlands koophandel en zeevaard 2, nos. 54-57 (1770): 425-50. The writer's
} 
early nineteenth-century humorous Dutch Ashkenazi Purim productions. The "Jewish Question" emerged as a new theme in the Purim's carnival tradition, where it became entangled with scatological humor as well as the reversal of social order. ${ }^{3}$ As a result, the Purim productions' focus shifted from absurd humor to the hardships of Jewish life. This essay will investigate the appearance in the Purim productions of contemporary political issues surrounding the Ashkenazi community in Amsterdam, such as the unproductivity and the poverty of the Jews. The Purim productions' Jewish writers engaged pejorative representations and employed humor in order to cope with and address the Jewish Question. As such, self-reflection "marked the fault lines of Jewish modernity." ${ }^{4}$ Moreover, this essay will discuss the Ashkenazi Purim productions from a historical perspective and, consequently, demonstrate that humor became a powerful tool for Jewish cultural and social change. ${ }^{5}$

Because of the scatological humor found in both Purim plays (purimshpieln) and Purim papers (purimkrantn), most contemporary scholars have dismissed the genre, considering it to be "coarse" and "low culture," satisfying the needs of only the Jewish proletariat. ${ }^{6}$ The critic Zishe Kornblith has written off the genre as follows: "For the intelligent person with a more

identity is a matter of dispute among scholars. Jozeph Michman is of the opinion that it is Isaac de Pinto. Odette Vlessing is of the opinion that the writer is not Jewish because of the proposal to move the Sabbath to Sunday. And Ton Jongenelen postulated that the proposal was actually penned by the De Koopman editor, Willem Ockers, himself; because Dutch editors were usually single-handedly responsible for the entirety of a journal's content, their pieces often appeared anonymously or pseudonymously. See Jozeph Michman, David Franco Mendes: A Hebrew Poet (Amsterdam, 1951), 134; Odette Vlessing, "The Jewish Community in Transition: From Acceptance to Emancipation," in "Proceedings of the Seventh International Symposium on the History and Culture of the Jews in the Netherlands: Expectation and Confirmation: Two Hundred Years of Jewish Emancipation in the Netherlands," ed. H. Berg, J. Frishman, S. A. Herman, and A. K. Offenberg, Studia Rosenthaliana 30, no. 1 (1996): 195-212, 197; and Ton Jongenelen, "Mordechai: Illusie en werkelijkheid in het spectatoriale blad De Koopman," Mededelingen van de Stichting Jacob Campo Weyerman 26, no. 2 (2003): 94-105, 97-100. See also J. C. E. Belinfante and Peter Buijs, "De Gelijkstaat der Joden: Inburgering van een minderheid," in De Gelijkstaat der Joden: Inburgering van een minderheid, ed. Hetty Berg (Amsterdam, 1996), 7-14, 8; and Peter Buijs, "Tot nut en eer van 't jodendom: Joodse genootschappen in Nederland," in ibid., 15-24, 17.

${ }^{3}$ Israel Davidson likewise observed a shift in themes in the Hebrew parody of the nineteenth century. See Israel A. B. Davidson, Parody in Jewish Literature, 2 vols. (New York, 1907), 2:58-59.

${ }^{4}$ David G. Roskies, "Major Trends in Yiddish Parody," Jewish Quarterly Review 94, no. 1 (2004): 109-22, 111.

${ }^{5}$ Unless otherwise stated, Jews refers to Ashkenazi Jews.

${ }^{6}$ See Marion Aptroot, "Western Yiddish Yontev-bletlekh: Facing Modernity with Humor," Jewish Studies Quarterly 15, no. 1 (2008): 47-67, 56; Leo Fuks, "Van Poerimspelen tot Poerimkranten," Maandblad voor de Geschiedenis der Joden in Nederland 1, nos. 6-7 (1947/1948): 162-76, 168-69; and Caroline Eitje, "Een aardige vondst in de bibliotheek 
or less developed aesthetic feeling, the great, huge difference between the creation of a poet and the cobbled-together work of a shund-writer-even the best of them-is so clear that it stares him in the face."7 This tendency to classify Yiddish theatrical expressions as shundliteratur, or "street literature," and the need for scholars to justify their objects of study remain, even nowadays, irresistible. ${ }^{8}$ Marion Aptroot excuses herself by stating that, even though the purimkrant was not of a high literary standing, it nonetheless has historical value, and Ahuva Belkin views the genre from an anthropological perspective, stating that "grotesque humor" and "obscenities" were a genuine expression of "folk culture." " Lacking aesthetic motives, shund writers had only financial motives - or so many historians argue. ${ }^{10}$ Their deplorable economic situations, rather than creative zeal, stimulated such productions. Because of the connection between poverty and the supposedly low cultural status of the purimkrant, Caroline Eitje even regarded the shund writers as "silent beggars," distinguished from professional beggars only by their education: "Although their Dutch is full of errors, they at least produced something that could be passed off as poetry or prose." 11 The emphasis on financial motives reflects an uneasiness with the Purim productions' literary content and neglects the public's demand for humorous literature.

Purim productions became for the late eighteenth-century Jewish community an important tool with which to mock the social order. Criticism has always been an element of Purim productions, from their first appearance in the Middle Ages up to contemporary times. ${ }^{12}$ However, the object of criticism has differed. For instance, from the sixteenth through the eighteenth centuries, the purimshpiel focused its critique on Christian hegemony by letting the villain Haman be played by a Christian carrying a cross. ${ }^{13}$ The earliest known Purim plays closely follow the biblical narrative of the book of Esther, comically reversing the social order, but refraining from social critique. This Purim tradition continued well into the eighteenth century, with parody and switching between the holy and the profane becoming the important

van Etz-Chajiem," Maandblad voor de Geschiedenis der Joden in Nederland 1, nos. 6-7 (1947/1948): 177-80, 177.

${ }^{7}$ Cited in Joel Berkowitz, ed., Yiddish Theater: New Approaches (Portland, OR, 2003), 7.

${ }^{8}$ Jacob Schatz, "Purimshpieln oen leytsim in amsterdamer getto," Yivo Bleter 19, no. 2 (1942): 212-20, 217.

${ }^{9}$ Aptroot, "Western Yiddish Yontev-bletlekh," 67; Ahuva Belkin, "The 'Low' Culture of the Purimshpil," in Berkowitz, ed., Yiddish Theater, 29-43, s33.

${ }^{10}$ Aptroot, "Western Yiddish Yontev-bletlekh," 66; Fuks, "Van Poerimspelen tot Poerimkranten," $167-68$.

${ }^{11}$ Eitje, "Een aardige vondst in de bibliotheek van Etz-Chajiem," 179.

${ }^{12}$ For the idea of Purim as (violent) Jewish agency, see Elliot Horowitz, Reckless Rites: Purim and the Legacy of Jewish Violence (Princeton, NJ, 2006).

${ }^{13}$ Chone Shmeruk, Yiddish Biblical Plays, 1697-1750 (Jerusalem, 1979), 103. 
humorous elements. ${ }^{14}$ This began to change with the new Akhashveyroyshshpils (Ahasheverus plays) in the eighteenth century, and especially with the Amsterdam Akhashveyroysh-shpil of 1780, as the genre began to show signs of incorporating local issues. These new plays subsequently influenced later maskilic drama. ${ }^{15}$

As was the case more generally, such theater was often critical of society. For instance, through his play Nathan the Wise, Lessing sought to foster religious toleration by reproducing the parable of the ring and by letting a Jew play the role of the honorable and enlightened Nathan. Furthermore, maskilim used the theater to address social issues. However, instead of blaming society for the Jews' inferior position, as Lessing did, they instead criticized the Jews' inability to cope with modern times. For example, Reb Henokh: Oder vos tut me damit (1793), by Isaac Euchel (1756-1804), and Leichtsinn und Frömmelei: Ein Familiengemälde in drei Aufzügen (1796), by Aaron Wolfssohn (1754/1756-1835), describe the crisis of bourgeois German Jewry-its generational conflicts and sexual deviance-as well as the rigid response of orthodoxy to anything new, such as modern headwear and maskilic study with its emphasis on (biblical) Hebrew grammar. ${ }^{16}$ These plays break with the early modern and late medieval Purim plays and mark what Jeremy Dauber has characterized as "the beginning of a strategic shift by the Jewish Enlighteners from external defensiveness to internal critique." 17

In the Netherlands, the Jewish society Felix Libertate [Happiness through freedom], open to adherents of all religions, supported the emancipatory theater productions. ${ }^{18}$ J. C. Hespe, a Christian member of the group, regarded it as a vehicle to promote social change and education. ${ }^{19}$ In particular, the

\footnotetext{
${ }^{14}$ Evi Butzer, Die Anfänge der jiddischen Purimshpiln in ihren literarischen und kulturgeschichtlichen Kontext (Hamburg, 2003), 114. See also Shmeruk, Yiddish Biblical Plays, 20-40.

${ }^{15}$ Jeremy Dauber, Antonio's Devils: Writers of the Jewish Enlightenment and the Birth of Modern Hebrew and Yiddish Literature (Stanford, CA, 2004), 182-83.

${ }^{16}$ Shmuel Feiner, The Jewish Enlightenment, trans. Chaya Naor (Philadelphia, 2002), 357.

${ }^{17}$ Dauber, Antonio's Devils, 164.

${ }^{18}$ Felix Libertate was a Jewish patriotic society that supported the Batavian Revolution. While it was open to all denominations, most of its members were Ashkenazim. Moreover, it played a pivotal role in the Emancipation Decree of 1796 granting all Jews legal equality. See Jozeph Michman, Dutch Jewry during the Emancipation Period: Gothic Turrets on a Corinthian Building, 1787-1815 (Amsterdam, 1995); and Salvador Bloemgarten, Hartog de Hartog Lémon, 1755-1823: Joodse revolutionair in Franse Tijd (Amsterdam, 2007), 37-84.

${ }^{19}$ Timothy De Paepe, "'Heavens! Jews on the Stage?"' (paper presented at the symposium "Places of Encounter," March 14, 2013, Antwerp). This view was also held by the chief rabbi of Amsterdam, Samuel Berenstein, who in a sermon praised writers such as Molière, Shakespeare, Schiller, and Klopstock for their plays' moral messages. See Samuel Berenstein, Leerrede over Psalm CXII: Vers 9 (Groningen, 1807), 9-10.
} 
theater company of the playwright Jacob Hartog Dessauer was known for its support of both Felix Libertate and the ideals of the French Revolution. ${ }^{20}$ The choice of certain theater pieces reflects Dessauer's political affiliation and emancipatory program. On May 28, 1795, during the Batavian Revolutionin which France dismissed the sitting government with help of the Orange Party - the company performed a German translation of Antonio Salieri's opera Axur, oder der persianische Feldherr Tarare. This opera tells the story of the Oriental tyrant Axur who is replaced by Tarare, a king elected by the people. It was first performed in 1787 in Paris and is closely connected to the French Revolution, for it reflects the political turmoil of the years preceding the Revolution while at the same time predicting its outcome. The story of the replacement of a tyrant by an elected leader shares many similarities with Felix Libertate's criticism of the misconduct and abuse of power of the parnasim. In the last scene of the opera, which takes place after the curtains have closed, Dessauer appears on the stage and proclaims that, like King Axur, "all political lies, all ignorance and all ancient prejudices will be chased away from their throne and out of the country, as stepchildren of the only true government." 21 The joyous atmosphere of the theater enabled maskilim such as Dessauer to reach the Jewish masses in a lighthearted way.

Likewise, the genre of the Ashkenazi Purim productions was an excellent medium through which to communicate serious matters in an attractive and not overly serious way. Around the year 1800, an abundance of Ashkenazi Purim productions was produced, yet, after only a few decades, the genre had almost ceased to exist. ${ }^{22}$ The sudden increase of so many ephemeral Ashkenazi Purim productions can be seen as a direct consequence of the abolition of Jewish semiautonomy, the loss of religious social control, and a decline in individual zeal. In the years surrounding the emancipation of the Jews in the Netherlands in 1796, Dutch maskilim produced many pamphlets, and, consequently, many maskilic themes entered the Purim productions.

The Dutch Haskalah has many different interpretations among historians, who tend either to downplay the Mendelssohnian influence or else to high-

\footnotetext{
${ }^{20}$ It is interesting to note that Dessauer's group was the first Jewish professional theater group and that it had more than thirty actors, including both men and women. Dessauer established his own theater school, where he trained actors and actresses. Hetty Berg, "Thalia and Amsterdam's Ashkenazi Jews in the Late 18th and Early 19th Centuries," in Dutch Jewry: Its History and Secular Culture (1500-2000), ed. Jonathan Israel and Reinier Salverda (Leiden, 2002), 191-200, 192-94.

${ }^{21}$ Cited in De Paepe, “'Heavens! Jews on the Stage?" 5.

${ }^{22}$ It is telling that the (Dutch) maskil Sommerhausen, known for his emancipatory writing, produced a Haggadah parody. In line with many maskilic endeavors, Sommerhausen focused on Jewish classical works, but he did not use the opportunity to spout criticism. See Tzvi Hirsch Sommerhausen, Haggadah leleil shikurim (Brussels, 1842).
} 
light it. ${ }^{23}$ Orthodoxy and moderate reform characterized the Dutch Haskalah in contrast to the German Haskalah. ${ }^{24}$ The Dutch Jews never witnessed a sweeping, radical reform of the Jewish communities. Massive conversion to Christianity, or even religious assimilation, did not occur in the Netherlands. In addition, the reform movement never gained any sort of foothold, and the question of the "missing reform" movement dominated the research agenda of historians. ${ }^{25}$ Unlike in Germany, the maskilic elite failed to radically reform and alter the Dutch Jewish landscape. This was partly due to the nature of the Dutch Haskalah movement. The Dutch maskilim resembled the maskilim of the early Berlin Haskalah in maintaining a strong Jewish religious identity. ${ }^{26}$

Under French rule, along with the establishment of Felix Libertate, the naye kille - the small maskilic community that seceded from the alte kille (the old Jewish community) and was officially known as Adath Jesserunmade the maskilim a powerful influence among the Dutch Jews. However, the naye kille was forcefully abolished in 1808, and afterward maskilic radicalism ceased to exist. The constant wish for compromise, or what the historian Bart Wallet has characterized as the Dutch desire for the "middle," led to moderate reform, in which radical ideas were continuously counterbalanced by the orthodox faction in order to maintain one community. ${ }^{27}$ It is not sur-

\footnotetext{
${ }^{23}$ For the relationship between the Dutch Haskalah and the German, see Fréderique van Cleeff-Hiegentlich, "Reflections on the Relationship between the Dutch Haskalah and the German Haskalah," in Dutch Jewish History I, ed. Jozeph Michman and Tirtza Levie (Jerusalem, 1984), 207-18; Irene E. Zwiep, "Jewish Enlightenment Reconsidered: The Dutch Eighteenth Century," in Sepharad in Ashkenaz: Medieval Knowledge and Eighteenth-Century Enlightened Jewish Discourse, ed. Resianne Fontaine, Andrea Schatz, and Irene E. Zwiep (Amsterdam, 2007), 281-311, and "A Maskil Reads Zunz: Samuel Mulder and the Earliest Dutch Reception of the Wissenschaft des Judentums," in The Dutch Intersection: The Jews and the Netherlands in Modern History, ed. Yosef Kaplan (Leiden, 2008), 301-18; and Jozeph Michman, Michmanei Yosef: Studies on the History and Literature of the Dutch Jews (Jerusalem, 1994), 245-62. On the idea of the absence of Haskalah in the Dutch Jewish community, see Irene E. Zwiep, "Jewish Enlightenment (Almost) without Haskalah: The Dutch Example," Jewish Culture and History 13, nos. 2-3 (November 2012): 220-34.

${ }^{24}$ One could argue that, because of their religious observance, moderate reform, and endeavors to revive biblical Hebrew, the Dutch maskilim can best be compared with the early Haskalah. See Feiner, The Jewish Enlightenment, 36-67.

${ }^{25}$ Bart Wallet, Nieuwe Nederlanders: De Integratie van de Joden in Nederland, 1814-1851 (Amsterdam, 2007), 175-76.

${ }^{26}$ As will be seen below, in the Diskursn, e.g., the naye kille (new community) used religious observance as a polemical tool to discredit the alte kille (old community). See Tsila Rädecker, "Making Jews Dutch: Secular Discourse and Jewish Responses, 1796-1848” (Ph.D. diss., University of Groningen, 2015), 103, 161; David Sorkin, The Transformation of German Jewry, 1780-1840 (New York, 1987); and Feiner, The Jewish Enlightenment.

${ }^{27}$ Wallet, Nieuwe Nederlanders, 173-76.
} 
prising, then, that this moderate tone also distinguished the maskilic themes in Purim productions.

This essay's focus on the Ashkenazi Purim productions does not suggest that the Sephardic community of Amsterdam did not develop a Purim theater culture. The Dutch Sephardim had a rich and diverse Purim culture and produced many Purim plays. Moreover, they were known for organizing luxurious balls. ${ }^{28}$ However, Sephardic theater differed profoundly from Purim theater as it was directed toward a more learned audience. ${ }^{29}$ Moreover, the Sephardic community was not, according to maskilim and Dutch contemporaries, in need of social and cultural transformation. In fact, the Sephardim served as a maskilic ideal toward which the Ashkenazim aspired. ${ }^{30}$ This was more an idealized image than a realistic reflection of the Sephardic community, which, during the eighteenth century, suffered economic decline resulting eventually in impoverishment. ${ }^{31}$ In what follows, I historically contextualize the Ashkenazi Purim productions and show that the themes of poverty and unproductivity reflected contemporary concerns.

\section{The Purim Productions' Genre and Audience}

The majority of the purimshpieln were elaborations on the Purim story: Esther saves the Jews from destruction by convincing King Ahasheverus of Haman's wickedness. However, many Purim productions adopted and Judaized non-Jewish theater; Christian mystery plays as well as the German Fastnachtspiel and the Italian commedia dell'arte influenced them profoundly. ${ }^{32}$ In content as well as in language, the purimshpiel played with conventions. It was unstructured and full of transvestism and obscenities. Reversal of the social order led to ridiculous subversive behavior. For instance, the pious man Mordechai sings the following address to the king: "Happy New Year, stinking eggs. May the king's balls grow and swell." Men played Esther's part, inverting her supposed beauty by rendering her grotesque, comparing her to a frog, and calling her a daughter of a whore. ${ }^{33}$

\footnotetext{
${ }^{28}$ Mozes Heiman Gans, Memorboek: Platenatlas van het leven der Joden in Nederland van de Middeleeuwen tot 1940 (Baarn, 1971), 216-20.

${ }^{29}$ Butzer, Die Anfänge der jiddischen Purimshiln, 33.

${ }^{30}$ See Ismar Schorsch, "The Myth of Sephardic Supremacy," Leo Baeck Institute Year Book 34 (1989): 47-66; and Andrea Schatz, "Returning to Sepharad: Maskilic Reflections on Hebrew in the Diaspora," in Fontaine, Schatz, and Zwiep, eds., Sepharad in Ashkenaz, 263-77.

${ }^{31}$ Tirtsah Levie Bernfeld, Poverty and Welfare among the Portuguese Jews in Early Modern Amsterdam (Oxford, 2012), 65-66.

${ }^{32}$ Shmeruk, Yiddish Biblical Plays, 18-19; Joel Berkowitz and Jeremy Dauber, eds., Landmark Yiddish Plays: A Critical Anthology (New York, 2006), 7-8.

${ }^{33}$ Belkin, "The 'Low' Culture of the Purimshpil," 30 (quote), 40.
} 
Humor, rather than absolute fidelity to the biblical story, was the focus of Purim theater pieces. Around 1800, purimkrantn were produced in Amsterdam, often no more than a couple of pages long and printed on cheap paper. These ranged from poems, to conversations, to parodies, to pastiches. ${ }^{34} \mathrm{Ja}-$ cob Dessauer-a German immigrant who moved to Amsterdam in 1784created, as we have seen, a number of Purim productions, all characterized by a strong emancipatory agenda. ${ }^{35}$ Shloume Duikelaar, a shoemaker, wrote the majority of Purim productions. ${ }^{36}$ (His name is still in use in contemporary Dutch, where it has become a pejorative term referring to a drip. ${ }^{37}$ His brochures were written mainly in the first person and consisted of a mixture of everyday life and fictive absurdities. A considerable number of eighteenthcentury Purim productions were printed anonymously because the parnasim prohibited their distribution. ${ }^{38}$ In a February 16, 1790, announcement, the producers were warned (with the help of a talmudic allusion): "Whoever speaks obscenely, even if a sentence of seventy years' happiness has been sealed for him, it is reversed for evil" (see Babylonian Talmud Shabbat 33a). Consumers caught buying, reading, or listening to these "mockeries" were targeted as well:

For years, the parnasim have seen the appearance of purimkrantn filled with obscene language and mockery and who[ever] reads it sins greatly. Therefore, to prevent such a thing from happening, the parnasim absolutely forbid the printers to print. And then we discovered that people looked for other ways to reach their audience with those bad writings. Therefore, we warn strongly that if you gather copies of such kranten or writings under whatever

\footnotetext{
${ }^{34}$ Aptroot, "Western Yiddish Yontev-bletlekh," 52.

${ }^{35}$ De Paepe, "'Heavens! Jews on the Stage?" 2. See also Berg, "Thalia and Amsterdam's Ashkenazi Jews," 191-92.

${ }^{36}$ For a listing that includes Shloume Duikelaar's and many other Dutch Yiddish publications, see Mirjam Gutschow, Inventory of Yiddish Publications from the Netherlands, c. 1650-c. 1950 (Leiden, 2007).

${ }^{37}$ Justus van de Kamp and Jacob van der Wijk, Koosjer Nederlands: Joodse woorden in de Nederlandse Taal (Amsterdam, 2006), 594.

${ }^{38}$ Besides prohibiting the Purim productions, the parnasim also tried to limit the exuberant Purim festivities, concerned by their disruptive elements. On Purim, many Jews dressed in costume and drank excessively in order to fulfill the religious prescription that one should not be able to distinguish between the hero Mordechai and the villain Haman. Furthermore, on the Fridays before and after, groups of Jews would sing Purim songs and beg for alms in the Jewish Quarter. Those purimverschteerders or verschtellers often disrupted the peace and violated their religious obligations. Every year when the holiday of Purim was approaching, the parnasim issued a warning concerning religious observance. Protocolbuch IV, pp. 2, 68, 100, GAA 714, Gemeente Archief Amsterdam.
} 
name they are known, the community guards will confiscate them. And when there are people on poor relief, they will forever be denied. Who holds his mouth and his tongue, keeps his soul from trouble [see Prov. 21:23] and the Lord will bless your strength, amen. $^{39}$

As the warning suggests, purimkrantn were frequently read in public. It appears that only one person needed to purchase a copy, which could then be read to many, enabling those who either could not read or could not afford a purimkrant to enjoy the content. Considering the quantity of copies of purimkrantn distributed either by anonymous writers and printers or by known print houses such as Proops, the interdictions were futile. ${ }^{40}$ In the Netherlands, satiric literature was extremely popular, and many such pamphlets, brochures, regular journals, and enlightened journals were available. Ephemerality characterized the genre, and most of the periodical publications disappeared as quickly as they were founded. ${ }^{41}$ During the last quarter of the eighteenth century, Dutch satire focused predominantly on the political rift between opponents and supporters of the House of Orange, patriots and orangisten, respectively. The Diskursn-polemical pamphlets issued in the years 1797 and 1798 by both the alte kille and the naye kille in which one community attempted to discredit the other-also supplied the high demand for satire and had similarly strong political objectives. ${ }^{42}$ The Purim productions not only fit into the existing Dutch satiric tradition but were also influenced by it.

Purim productions and festivities attracted all layers of society. For instance, in 1778, the Sephardic rabbi and emissary Haham Azulay visited Amsterdam and watched a purimshpiel at the home of the chief rabbi, Saul Löwenstamm (1717-90). As Azulay recounts:

In the meantime, a fool arose and gave a speech. He spoke Hebrew in doggerel and cited a story from the Talmud (Kiddusin 39b) that

\footnotetext{
${ }^{39}$ Ibid., 2.

${ }^{40}$ Contrary to Marion Aptroot, who regards the middle class as the target audience of the purimkrantn because of their price, I believe that they were read aloud in public places, which means that wealth was not a prerequisite for familiarity with the genre. See Roger Chartier, Cultural Uses of Print in Early Modern France, trans. Lydia G. Cochrane (Princeton, NJ, 1988), 159; and Jeroen Blaak, Geletterde Levens: Dagelijks lezen en schrijven in de vroegmoderne tijd in Nederland, 1624-1770 (Hilversum, 2004), 20.

${ }^{41}$ See Pieter van Wissing, ed., Pers en Politiek tussen 1780 en 1800: Stookschriften (Nijmegen, 2008); Pieter van Wissing, Stokebrand Janus 1787: Opkomst en ondergang van een achttiende-eeuws satirisch politiek-literair weekblad (Nijmegen, 2003); and Pieter van Woensel, De Lantaarn: Satirische teksten uit de achttiende eeuw (Amsterdam, 2002).

${ }^{42}$ See Jozeph Michman and Marion Aptroot, eds. and trans., Storm in the Community: Yiddish Polemical Pamphlets of Amsterdam Jewry, 1797-1798 (Cincinnati, 2002).
} 
related to the [commandments to] honor your father and mother (Deut. 22:7) and to send away the mother while collecting eggs from the nest (Deut. 5:16). Both commandments are accompanied by the sentence "so may your days be lengthened." One day a father ordered his son to climb a wall and to take the eggs from a nest. The boy did it according to the laws of Torah, but tripped during his descent and dropped dead. The Gemara (Talmud) explains the "lengthening of life" as a reference to the afterlife, namely the perfect life of the 'olam ha'ba. He [the fool], however, thought otherwise and explained: on the earth ('olam ha'zeh). Because the boy was standing on a wall, the promise was not fulfilled. ${ }^{43}$

The joke here is the literal translation of the concept of 'olam ha'zeh. Theologically, 'olam ha'zeh means "life on earth." However, the fool translates it as "on the earth," and, because the boy stood on the wall, his life was not lengthened in the world to come ('olam ha'ba). Because the concept of 'olam $h a^{\prime} z e h$ is translated incorrectly, the initial talmudic explanation is completely reversed. This critique of extreme talmudic reasoning such as pilpul (casuistic hairsplitting) was a beloved theme for many maskilim, who were critical of the rabbinate for its purported unreasonableness and ignorance. ${ }^{44}$

Moses Löwenstamm, who succeeded his father Saul as chief rabbi of Amsterdam, also appreciated the Purim festivities and did not shy away from critiquing the Jewish community. Sometime between 1794 and 1798, an untraditional purimshpiel was performed at his house mocking the Jewish community and its charity system. The anonymous play, titled by its founder, Leo Fuks, Alz der sof iz gut, iz allez gut [All is well that ends well], deviates from the biblical story line commonly used in purimshpieln. It is an update of the Esther story, and the plot revolves around a hypocrite who deceives the ruling elite and is later dispatched by the main hero. ${ }^{45}$ Although the theme of unmasking is pivotal in Alz der sof iz gut, iz allez gut, the plot also shares similarities with Dutch comedies such as the 1683 anonymous Yiddish play Den bedroge bedrieger [The deceived deceiver]. In these plays, the plot focuses on revealing the truth and exposing the imposter, which, in Alz der sof $i z$ gut, iz allez gut, is reflected in the use of telling adjectives such as dis-

\footnotetext{
${ }^{43}$ S. A. Vega, trans., "Chagam Azulay vertelt over Poerim te Amsterdam, 1778," Maandblad voor der Geschiedenis der Joden in Nederland (1947-48): 192-97, 194-95.

${ }^{44}$ See Jonathan Meir, Imagined Hasidism: The Anti-Hasidic Writings of Joseph Perl (Jerusalem, 2013); and Yehuda Friedlander, Bemistarei Hasatira: Hebrew Satire in Europe (Ramat-Gan, 1979).

${ }^{45}$ See Dauber, Antonio's Devils, 187.
} 
guised, betrayed, deceived, etc. ${ }^{46}$ Likewise, in Den bedroge bedrieger, the plot revolves around the unmasking of several characters. ${ }^{47}$

Other typical purimshpiel elements such as masquerades, marital problems, code switching, and cursing appear in Alz der sof iz gut, iz allez gut. One woman is dressed as a male servant, and the imposters are disguised as, respectively, a shadar (a shaliach derabanan, a legal emissary for the collection of settlements in distress or in the Holy Land) and a baal-shem (a miracle-working or wonder rabbi) from Galicia. Each character can be recognized by his or her dialect. Shifts in language also characterize these new versions of the Akhashveyroysh-shpil and the plays Reb Henokh and Leichtsinn und Frömmelei. Thus, the emissary from Jerusalem, Yerushalmi, speaks broken Hebrew, and the wonder rabbi expresses himself in Polish Yiddish. Other characters speak either German Yiddish or Dutch Yiddish. ${ }^{48}$ In each case, the theatrical attribute of language identifies the character. Also, the female character Lipke Yentes constantly curses at her deceitful husband, the disguised wonder rabbi Reb Yokesh. She calls him a "bastard" and a "rascal" and threatens to "scratch out his eyes and break all his teeth" if he continues lying. ${ }^{49}$ However, one typical element missing in the play is the explicit use of sexual metaphors and insinuations. Instead, the play performed for Moses Löwenstamm mixes humor with social critique, which is directed at Jewish communal life.

Because of the traditional critical function of the Purim productions, these became an excellent format to include maskilic solutions to the Jewish Question. Traditionally, purimshpieln destabilized the social order. The realistic contemporary setting, the refraining from sexual and coarse elements, and the linguistic play all became (alongside political objectives) characteristic

\footnotetext{
${ }^{46}$ Leo Fuks, ed., All Is Well That Ends Well; or, The Uncovered Three-Fold Deceit: A Comedy in Three Acts: An Anonymous Yiddish Comedy from the End of the 18th Century, modernized Yiddish version (Paris, 1955), xi-xii.

${ }^{47}$ The comedy commences with the arrival of Yerushalmi in the house of the parnas of Amsterdam, Reb Lipman. Yerushalmi pretends to be a money collector from Jerusalem who speaks only broken Hebrew. However, in reality, he is a swindler from Galicia who has tricked his wife, Lipke Yentes, by sending her a letter telling her of his death. Yerushalmi is accompanied by a girl dressed as a boy whom he deceived into leaving her father's house. Because Lipke Yentes presumes that her husband is dead, she marries Reb Yokesh, a miracle-working rabbi from Galicia and a friend of Yerushalmi's. Reb Yokesh in turn also deserts Lipke Yentes and moves to Amsterdam. But Lipke Yentes follows him, and, in the house of the parnas Lipman, where eventually all the characters gather, the imposters are exposed. Yerushalmi returns to his wife Lipke Yentes, and Reb Yokesh marries the girl disguised as a servant boy.

${ }^{48}$ For a discussion of the different dialects and languages used in the Alz der sof iz gut, iz allez gut, see Rena Fuks-Mansfeld, "West- en Oost-Jiddisch op het toneel in Amsterdam aan het einde van de achttiende eeuw," Studia Rosenthaliana 26, no 1 (1996): 91-96, 94-96.

${ }^{49}$ Fuks, ed., All Is Well, 8.
} 
elements of the maskilic reinvention of the Jewish theater tradition. Moreover, the large audiences and acceptance by the rabbinate provided excellent opportunities for maskilim to disseminate their ideas throughout all layers of society. Rich or poor, illiterate or educated, all in some way or another had access to the Purim productions' content.

\section{Poverty in the Dutch Purim Productions}

The Dutch Jewish Question focused on improving the financial state of the Jews. Since its founding in 1635, the Ashkenazi community struggled continuously to find sufficient financial resources, and its pinkasim (notebooks of the Jewish community) are full of references to the enormous number of poor Jews. In 1799, 87 percent of Dutch Ashkenazi Jews were on poor relief. ${ }^{50}$ This unfortunate economic situation declined further during times of war, such as the Fourth War with England (1780-84) and the subsequent French invasion (1795). Not only did Ashkenazi Jews witness increased poverty, but the Sephardim were also, as has been noted, rapidly impoverished as a result of the general economic decline. ${ }^{51}$ Jewish poverty was caused, according to the Dutch maskilim, by the parnasim's abuse of power, inequality, lack of education, and a refusal to let go of outmoded rituals.

The maskilic writers of the Diskursn of the naye kille criticized the parnasim for maintaining backward Jewish rituals that kept the Jews deprived. Moreover, they contended, the parnasim consolidated and preserved the disparity between rich and poor in the observance of Jewish law because only rich Jews were able to perform honorary functions in the synagogue. ${ }^{52}$ The maskilic theme of poverty and the connection to the Jewish community's mismanagement also found their way into Dutch Purim productions. They inspired Duikelaar to compose the following verse in Di naye befrorene Purim krant [The new frozen Purim paper]:

What can we write about wintertime, dear folk, that we carried the yoke.

\footnotetext{
${ }^{50}$ Jozeph Michman, Hartog Beem, and Dan Michman, Pinkas: Geschiedenis van de joodse gemeenschap in Nederland (Ede, 1992), 59. The number of Jews receiving poor relief is uncertain as scholars tend to view all Jews eligible for the matze distribution as poor. See Marco H. D. van Leeuwen, "De Gelykstaat der Joden: Inburgering van een Minderheid," in Arme Amsterdamse Joden en de strijd om hun integratie aan het begin van de Negentiende eeuw, ed. Hetty Berg (Amsterdam, 1996), 55-66, 58-59.

${ }^{51}$ See Bernfeld, Poverty and Welfare, 65-66.

${ }^{52}$ See, e.g., Diskursn 1 of the naye kille, in Michman and Aptroot, eds. and trans., Storm in the Community, 28-61, passim.
} 
This year there was a lot of snowfall and also wind and squall.

For the poor, this winter has never been so bad, and a bit of mercy we have not had.

The people amused themselves this wintertime and showed us poor no respite.

Winter is good, they say,

but our goods and chattels we have eaten away.

He mentions the difference between the rich and the poor and blames the former for not taking care of the latter and providing poor relief. The rich happily carry on, oblivious to the needs of the unfortunate. Duikelaar, however, feels guilty: "And I have thought about the poor with no food and no goods. A household with small children, with no bread or fire to warm them. Poor them, all winter without earnings-and when I think of that my joy disappears." 53

In a purimkrant by Duikelaar, one of the humorous elements is devoted to a fictional price list wherein worthless items are assigned absurdly high prices. ${ }^{54}$ Di naye Purim krant: Beschraybung fun di dray berumte sokhrim [The new Purim paper: Description of the three famous merchants]. For instance, one of the items on the list reads: " 43 sleeveless shirts, torn in front, shat upon on the back, 40 two-and-a-half-guilder coins, 4 baize skirts with fleas, ditto white ones with misfortune in them...."55 The prices of food and clothing were important issues for the impoverished Dutch Jewry. The Amsterdam chronicles by such authors as Abraham Haim Braatbard, Zalman Prins, and Bendit Benjamin Wing echo this economic concern. ${ }^{56}$ They often mention the price of various (food) items during their descriptions of events in the Republic as well as in their own Jewish community. For them, food prices were of vital importance.

Price as a continuing theme thus appears in various guises and sometimes reinforces other themes associated with poverty, such as the winter season. $D i$ naye Purim krant connects typical winter activities with the time of the Purim

\footnotetext{
53 A naye Purim lukh, fol. 5. See also Fuks, "Van Poerimspelen tot Poerimkranten," 172.

${ }^{54}$ The construction of absurd (price) lists was a common device. It appears not only in Purim productions but also in, e.g., Sommerhausen's Haggadah leleil shikurim, in which every known wine is mentioned in alphabetical order. See Sommerhausen, Haggadah leleil shikurim, 28.

${ }^{55}$ Di naye Purim krant: Beschraybung fun di dray berumte sokhrim, YidNed 450, fol. 00, Library Rosenthaliana, Amsterdam.

${ }^{56}$ For an elaborate discussion of those chronicles, see Bart Wallet, "Links in a Chain: Early Modern Yiddish Historiography from the Northern Netherlands, 1743-1812" (PhD diss., University of Amsterdam, 2012), 216-37.
} 
play's composition, which was sometime between February and March: "The children are very happy and have cried. Tomorrow our father will buy us ice skates. For each of the children he will buy a pair of ice skates for nine guilders." ${ }^{57}$ Compared to the average wage of one guilder per day for an unskilled laborer, this price was very high. ${ }^{58}$ Di naye Purim krant further discusses the cost of rye bread during the winter: "We have never had such a winter when it was much cheaper [to live] than all the other years; I don't know why the poor complain, moan, and cry because 'of the bad times.' One loaf of rye bread, which has cost other years 15 two-and-a-half-guilder coins, costs this wintertime 10 two-and-a-half-guilder coins." 59 Of course, even though the price of rye bread has decreased, it remains ridiculously high. The relative improvement in an unfortunate situation serves here as a comic device. The constant reference to prices in various Purim productions demonstrates self-mockery as a strategy for coping with the poor economic situation of Ashkenazi Jews.

Poverty in relation to an inability to observe Jewish law occurs in a bilingual Purim production by Duikelaar, Nayen yors und ekstra simkhes-toure kurant beningn Lekere Kheritkhe [New Year's and special Simhat Torah paper to the tune of "The Accomplished Wife Gerritje"]. In this poem, Reb Henokh complains about the expenses of the high holidays. He mentions, among other things, the costs connected to the observance of Jewish law. He laments the price of "honey and sweet apples for Rosh Hashanah, the grapes to say a blessing over, kosher wine for the blessing of the wine, a lulav and etrog for Succoth." ${ }^{60}$ By pointing out the costs of religious observance, Duikelaar tentatively addresses the political issue of inequality.

His self-reflection and maskilic agenda are evident when Duikelaar directs his criticism toward the Ashkenazi poor, condemning their passivity and continuous requests for money. In a lengthy exposition, he lists all his generous gifts to the poor, who continue to beg for alms:

That's why I have given away enough. But how can you give away the whole world? Between us, I have given the clerics a roaster [a young chicken] of 150 guilders. To me came the poor, they did not have water, what should I do? In a room I had a barrel, I have let them take out as much water as they liked. To me came the poor, without heating. I had a lumberjack make a couple of yards

\footnotetext{
${ }^{57}$ A naye Purim lukh, fol. 4.

${ }^{58}$ For wages in early modern Amsterdam, see H. Nusteling, Welvaart en Werkgelegenheid in Amsterdam, 1540-1860 (Amsterdam, 1985), 252.

${ }^{59}$ A naye Purim lukh, fol. 4.

${ }^{60}$ Nayen yors und ekstra simkhes-toure kurant beningn Lekere Kheritkhe, YidNed 523, fol. 2a, Library Rosenthaliana.
} 
of peat, and I distributed to everyone his share of peat and a bundle of sulfur. After that the poor came to me because they did not have carpets. I went to the carpet shop and got two carpets of six and five miles, respectively, which I cut into pieces. ${ }^{61}$

This long list exposes how, without a constructive solution, poverty would endure. The Jewish community's pinkasim confirm the accuracy of this observation of the many poor people begging for support. ${ }^{62}$ In line with Enlightenment thought, which stressed autonomy and agency, the Dutch maskilim did not accept Ashkenazi poverty as a fait accompli; they urged the poor to take matters into their own hands and change the Jewish future.

Implicit criticism of the relation between poverty and passivity appears in Alz der sof iz gut, iz allez gut. The play commences with a request to the Amsterdam Ashkenazi community to donate on behalf of the poverty-stricken community of Solnek in Poland. Their ritual enclosure (eruv) and keys to the ritual bath (mikveh) have been stolen, and, because "there is no money, nor in our pockets, nor in our houses and everything costs money, we [will] send a young man who shall visit the city and village to collect money." 63 The first lines of the play show the difficulty faced by the impoverished attempting to observe Jewish law, which requires money. The play mocks Polish Jews as incapable of solving their own problems, preferring to travel to other Jewish communities to beg for subsistence. The Polish Jew here represents the passive Jew.

Jewish self-criticism comes especially to the fore in the humorous spectacle of the Polish Jew in plays and Purim productions. The appearance of this character in Purim productions resulted from the continuous influx of poor Jewish immigrants from Eastern Europe into the Netherlands as a result of pogroms and their regrettable economic situation. Many Jewish inhabitants of the Dutch Republic were of Polish ancestry, and Polish Jews had a separate community up until $1673 .{ }^{64}$ The revealing title of another Purim production, Di Purim krant fon Poylen do iz niks tsu hoylen [The new Polish Purim paper: There is nothing to get], connects the Eastern European background of many Dutch Jews with poverty, and, in Di naye Hagode [The new Haggadah], a parody on the Haggadah, Duikelaar connects a lack of good food with a Polish heritage: "This is the bread. It is the bread of the poor. It is the poor man's bread what we have eaten with our parents at home in little

\footnotetext{
${ }^{61}$ Ibid.

${ }^{62}$ See Protocolbuch IV, pp. 2, 3, 6, 26, 45, 101, 169.

${ }^{63}$ Fuks, ed., All Is Well, 1.

${ }^{64}$ See Leo Fuks, "Oost-Joden in Nederland tussen beide wereldoorlogen," Studia Rosenthaliana 11, no. 2 (1977): 198-215.
} 
Poland. Pumpernickel bread with smelly goats' cheese." 65 For the general Ashkenazi community, the Polish Jew was the poorest of the poor.

The Polish Jew was represented by what was considered a typically derogatory image of a poor Jewish peddler with a beard and a Yiddish accent. ${ }^{66}$ Polish Jews were perceived as uneducated, poor, untrustworthy, and backward. The Jewish family name Polak, which indicated the family's former place of residence, became a pejorative stigma. For instance, the satiric writer Nicolaas Hoefnagel depicts the Polish Jew in the following parody: "I desire fish, as a smouse ${ }^{67}$ Polak smells, as though he did not shave his beard for a half year nor brush his hair." ${ }^{68}$ Maskilim also stereotyped the Polish Jew. In the Diskursn, for example, the Polish background of the chief rabbi of Amsterdam, Moses Löwenstamm, was continuously ridiculed. His Polish roots and accent were said to signify his ignorance of Jewish texts. This uncomplimentary image continued well into the nineteenth century, when Polish Jewish teachers especially were held responsible for the deplorable state of Jewish education. ${ }^{69}$ The Polish Jew came to symbolize everything wrong within the Dutch Ashkenazi Jewish community.

At the end of the eighteenth century, the maskilim criticized the way in which community leaders handled finances for the poor, accusing them of misconduct and mismanagement and of distributing the taxes benefiting the poor unfairly. According to members of the naye kille, the poor contributed more to poor relief funds than did the affluent, owing to the tax on offal and on good cuts of meat. Moreover, as was common in this period, the Jewish community distributed only the bare essentials to the poor, though this was

\footnotetext{
${ }^{65}$ Ibid., 25.

${ }^{66}$ In much satirical literature, such as in the writings of Nicolaas Hoefnagel, the Jew is depicted with a Yiddish accent by placing the letter $h$ in front of every word. Similarly, in the publications of Felix Liberate, the wrong use of the letter $h$ indicates a Jewish background. See Heil en Broederschap tusschen den Burger en den Jood: By gelegenheid der Heilryke Omwending van's Lands Zaaken in January 1795, en het Inweiden der Jooden Club op den $11^{\text {den }}$ February 1795 (Amsterdam, 1795).

${ }^{67}$ The word smouse probably derives from the name Moses and was used pejoratively to refer to Jews. Fréderique van Cleeff-Hiegentlich, "'Eerlijke smousen-hoe zien die "er uyt myn heer?' Of hoe er in de achttiende eeuw in de Republiek der Zeven Verenigde Nederlanden over joden werd gedacht—een verkenning," in Vreemd Gespuis, ed. Jan Erik Dubbelman and Jaap Tanja (Amsterdam, 1987), 56-65, 56-57.

${ }^{68}$ Nicolaas Hoefnagel, De Nederlandse Overweeger (Amsterdam, 1771-72), 78.

${ }^{69}$ According to a Dutch government official in 1806, Jewish education turned children into "de petits Polonais ou Allemands." H. T. Colenbrander, Gedenkstukken der algemeene geschiedenis van Nederland van 1795 tot 1840, 10 vols. (The Hague, 1910), 5:272. See also N. L. Dodde and M. M. P. Stuljens, "Jewish Education in Schools in the Netherlands from 1815 to 1940," Studia Rosenthaliana 30, no. 1 (1996): 67-87.
} 
hardly enough to sustain them: ${ }^{70}$ they received a small allowance, in wintertime they were given peat and clothing, and for Passover they received free matzo, allowing them to observe the holiday requirement.

Solutions to this immense poverty were linked to perceptions of the Jew. For the Dutch maskilim, the key to improvement lay in employment and equality. They proposed an equal distribution of poor relief and a tax system that was based on income. This way, those who had the most also contributed the most. In the maskilim's eyes, poverty derived from two sources, namely, the old communities system, which promoted and sustained poverty, and the reluctance of Jews to work in the crafts based on the previous prohibition against their acceptance to most of the guilds.

The writers of the Diskursn of the naye kille strongly condemned the parnasim for the unequal distribution of goods, which, along with indifference, maintained the dreadful poverty:

We have to do drudge work and suffer hardship; we can't hear the reading in the synagogue, since we're traveling to eke out a living. Still we are-thank God-Jews. We read about it when something happens for the good of the country or for the Jews in the world. But they, in their black coats, gorge themselves on capons and swill wine. They don't work hard or suffer. They don't have to; they live like lords and they don't bother about the poor man. They boast that they hear the reading three times a week and because of them the whole Jewish Quarter cries. They slap themselves on the belly: "Ek, mek we are it!" And ostensibly in the name of Jewishness, they cut the poor man's throat. ${ }^{71}$

Keeping the poor in a state of deprivation fostered inequality while boosting the status of the parnasim. Because of their wealth, the latter could attend synagogue and thus represent themselves as observant and more honorable Jews. Solving the problem of poverty would, therefore, lead to greater equality. In the eyes of the maskilic writers, the leaders benefited from the impoverished condition of most members of the Ashkenazi community. This critical stance was likewise present in the Dutch Purim productions, though in a somewhat milder form. The absurd price lists and references to poverty as well as the depiction of the Polish Jew as the poorest of the poor show that maskilic solutions and criticism of the Jewish Question were seamlessly entangled with the humorous framework of Purim.

\footnotetext{
${ }^{70}$ S. E. Bloemgarten, "De Amsterdamse joden gedurende de eerste jaren van de Bataafse Republiek (1795-1798)," Studia Rosenthaliana 2, no 1 (1968): 42-65, esp. 53.

${ }^{71}$ Michman and Aptroot, eds. and trans., Storm in the Community, 90.
} 


\section{Unproductivity in the Dutch Purim Productions}

According to the Dutch maskilim, Jewish unproductivity lay at the heart of the poverty and perceived backwardness of the Ashkenazim. The Jewish occupational structure was blamed for widespread deprivation. The residual effect of former restrictions was that Jews were predominantly employed in unskilled and low-paid professions. Only jobs outside the guilds had been open to Jews since the guilds accepted only Christians as members. The inability of Dutch Jews to work in manufacturing starkly decreased their economic opportunities. This meant that the majority were employed as unskilled laborers, such as porters, traders in secondhand goods, and peddlers. ${ }^{72}$

Although the Emancipation Decree of 1796 seemed to suggest that Jews could now officially work in the crafts, the slow implementation of the decree proved otherwise. Jews continued to be banned from joining the professional organizations of craftsmen. ${ }^{73}$ Moreover, the local government of Amsterdam ignored the new regulations regarding the legal equality of the Jews. ${ }^{74}$ The Jewish religion also contributed to a preference for employment in trade as this type of work enabled the earning of an income while observing the Sabbath and high holidays, which would have been impossible had wage labor been pursued. Maskilic initiatives to teach poor Jews a craft, such as the Vereniging voor arbeid en vlijt [Association for work and diligence], founded in 1805, and the Vrijwillig werkinstituut [Voluntary work institute], founded in 1810, failed in their attempts to create a more diverse Jewish workforce. ${ }^{75}$ The combination of historical rights, local government resistance, discrimination, and tradition resulted in the restricted access of Jews to crafts, a restriction that was carried over well into the nineteenth century. The overrepresentation of Jews in petty trade and in low-paying jobs contributed to a surfeit of rivalry and a dearth of work in the community ${ }^{76}$ Especially in wintertime, when business was slow, it was difficult for Jews working in economically sensitive jobs to earn a living. The Dutch Purim productions reflect this continuous struggle for employment. For instance, Duikelaar's Ez naye Purim buch [The new Purim book] notes the streetcleaners' unemployment: "This winter I had nothing to clean. I starved to death. My desire was modest.

\footnotetext{
${ }_{72}$ Van Leeuwen, "De Gelykstaat der Joden," 57.

${ }^{73}$ Karina Sonnenberg-Stern, Emancipation and Poverty: The Ashkenazi Jews of Amsterdam, 1796-1850 (Oxford, 2000), 99.

${ }^{74}$ Wallet, Nieuwe Nederlanders, $82-87$.

${ }^{75}$ Both initiatives were small, and the majority of the poor were very reluctant to apply. Gans, Memorboek, 326; letter dated July 31, 1827, GAA 5186-698, Gemeente Archief Amsterdam. ${ }^{76}$ Van Leeuwen, "De Gelykstaat der Joden."
} 
If only I could sweep the Breestreet, I would have money." 77 Unemployment was a common feature of European port cities such as Amsterdam, which depended heavily on seasonal workers. ${ }^{78}$ In that sense, lack of employment affected the whole city. Many crafts workshops produced goods for export, and traders trafficked in both imported and exported goods. Reduced economic activity at certain times of the year was thus typical not only of Jews; it was a general trend in early modern cities.

Sometimes it was difficult to discern the difference between beggars and unsuccessful merchants. For instance, Jewish beggars deported to camps in the northern Netherlands considered themselves to be merchants. ${ }^{79}$ The parodic Purim production Algebreisch und akurant almanak fir alle reyzende, gehende, farende, und zitsende leyten mit geld und zonder geld [The algebraic and accurate almanac for all traveling, moving, sailing, and sitting people with or without money] addresses this fine line between begging and business failure as it ridicules the habit many Jews had of considering themselves to be salesmen even when they had nothing to sell: "March-April fairs for all prominent businessmen who have no merchandise: Batavier ... The Folistreet ... Komkommermarket. ..." ${ }^{80}$ Referenced here are important trade markets and streets in the Jewish Quarter that were known for an abundance of Jewish peddlers, mostly selling similar items, all of questionable usefulness.

According to Dessauer, the disproportionate number of Jews in trade was responsible for the Jewish community's poverty. ${ }^{81}$ In a narrative song with the revealing title Arbeit und Fleiss [Work and diligence], Dessauer encourages Jews to learn a craft and explicitly addresses the question of Jewish productivity. This piece bears many similarities to Reb Henokh and Leichtsinn und Frömmelei as it clearly conveys a maskilic message intended to alter the behavior of the Jews. In it, two sisters are in search of a husband. Both a shoemaker and a tailor propose. However, the sisters are reluctant as they do not consider either one honorable or appropriate: "Oh no tailor, a tailor and a shoemaker, do you despise us? No, we want to marry merchants." 82

\footnotetext{
${ }^{77}$ A naye Purim lukh, fol. 2. Breestraat was the main street in the Jewish Quarter of Amsterdam.

${ }^{78}$ For cities' economic dependence on immigrants, see Charles Tilly, "Migration in Modern European History," in Human Migration: Patterns and Policies, ed. William H. McNeill and Ruth S. Adams (Bloomington, IN, 1978), 48-71.

${ }^{79}$ Letter dated July 31, 1827 (see n. 75 above).

${ }^{80}$ A naye Purim lukh, fol. 19.

${ }^{81}$ Because of the shift in content, the language, and the lack of humor, this brochure by Dessauer is regarded by Fuks and Aptroot as not a proper Purim production even though Dessauer himself labeled it as such. See Fuks, "Van Poerimspelen tot Poerimkranten," 176; and Aptroot, "Western Yiddish Yontev-bletlekh," 55.

${ }^{82}$ Jacob Hartog Dessauer, Arbeit und Fleiss, 2, YidNed 497, Library Rosenthaliana.
} 
As the reaction of the sisters demonstrates, professions such as shoemaker and tailor were frowned on. To boost the esteem of the artisan, Dessauer lets the tailor answer the sisters: "The craftsman is just as good as anyone else. If there were no craftsmen, there would be no merchants." The shoemaker continues: "A human is a man, when he is human and honest. The world is divided under various stars. We cannot become everything." Then the choir responds with the much-cited answer to the question of Jewish productivity: "We cannot all live from trade and live as merchants; variation in conduct can give us nourishment." ${ }^{83}$ Dessauer clearly intended to convince the Jews that working in crafts provided food and was therefore just as honorable as working in trade.

Toward the end of the song, the women are finally convinced of the respectability of the artisans and happily proclaim:

No, no, no, I will no longer tarry

I should quickly marry

As a woman ages

Her appearance changes

And if she doesn't have a lot of capital

A husband she will not get at all

Therefore a craftsman it will be

As he can provide for me

Better one than none. ${ }^{84}$

Here, Dessauer explicitly connects the artisan's productivity with usefulness. Being productive was an Enlightenment ideal, and this preoccupation with utility is reflected in various civic associations. The word usefulness appears in the names of various institutions, and it typifies the pivotal role attributed to civil society in the process of social change. Things were valuable only if they benefited humanity. For instance, the most important Dutch association aiming to civilize the masses was called the Maatschappij tot Nut van 't Algemeen [Association for the benefit of the common good]. Jews were, however, excluded from membership in it. ${ }^{85}$ In line with the value attributed to productivity, Dessauer praises the crafts. So the carpenter hammers, the weaver weaves, and the cook cooks; their professions are respectable as they all bring "bread to the table." In the final couplet, the ideas of respectability

\footnotetext{
${ }^{83}$ Ibid., 3. ("Wir können alle nicht vom Handel, Und als Kaufleute leben, Verschiendenheit in Lebenswandel, Kann uns Nahrung geben.")

${ }^{84}$ Ibid., 4.

${ }^{85}$ Merel Stikkelorum, "De Joodse gelijkberechting en de 'verlichte' praktijk: De Maatschappij tot Nut van 't Algemeen onder de loep 1796-1798," in Een veelzijdige verstandhouding: Religie en verlichting in Nederland, 1650-1850, ed. Ernestine van der Wall and Leo Wessels (Nijmegen, 2008), 358-73.
} 
and usefulness are once again expressed when the choir sings: "Being useful is our goal ... and the greatest art stays small when she is of no use to the world." 86

The Purim production Di Purim krant fon Poylen do iz niks tsu hoylen [From Poland there is nothing to obtain] further elaborates the connection between business failure and poverty. "It rains; I am so wet, I return. I do not have fun; I do not have a dime, chilblained hands and no money. What does one do to make money?" The difficult living conditions of the Jews and their employment in petty trade contributed to their inability to earn a decent living. Most worked in the same industry, which starkly decreased earning potential per person. They therefore traveled during the week, trying to sell their wares wherever possible. ${ }^{87}$ Others attempted, for better or worse, to sell their often-useless items in town or tried their luck as porters or carriers.

In their eagerness to sell as many items as possible, lively and often noisy selling methods caused numerous conflicts between Jewish merchants, guild members, and the city authorities. ${ }^{88}$ Jewish merchants presented their goods in the street and loudly proclaimed their prices. Repeatedly, city authorities as well as the Jewish community warned them to obey regulations and not disturb traffic or cause upheavals. ${ }^{89}$ Considering that such warnings recurred throughout the eighteenth century, attempts to control the Jewish merchants were apparently in vain. The need to earn a living probably far exceeded any threat of punitive measures.

The idea that unproductive Jews are worthless in themselves is explored in Antvert an Shloyme Duikelaar [Response to Shloume Duikelaar]. There, Duikelaar describes how he undertook a succession of trades in order to provide for his family. The brochure starts with a depiction of Duikelaar trying to cash in a lottery ticket at clearly inappropriate places (e.g., a farmhouse) and then moves on to his attempts to pursue various professions. For example: "I began with another profession, namely corn cutter (all feet are filthy). The first [corn] I cut with sharp knives until [the patient] was completely cut by my hands.... An apothecary and doctor had to help. What was my

\footnotetext{
${ }^{86}$ Dessauer, Arbeit und Fleiss, 4, 5.

${ }^{87}$ See Michman and Aptroot, eds. and trans., Storm in the Community, 468; Hetty Berg, Thera Wijsenbeek, and Eric Fischer, eds., Venter, fabriqueur, fabricant: Joodse ondernemers en ondernemingen in Nederland, 1796-1940 (Amsterdam, 1994); and van Leeuwen, "De Gelykstaat der Joden," 55-59.

${ }^{88}$ The chronicle of Braatbard refers extensively to the many upheavals between guild members and Jews. See Leo Fuks, trans., De zeven provinciën in beroering: Hoofdstukken uit een Jiddische kroniek over de jaren 1740-1752 van Abraham Chaim Braatbard (Amsterdam, 1960), 106-22.

${ }^{89}$ See, e.g., Protocolbuch II, pp. 13, 230, 305, 602, GAA 714, Gemeente Archief Amsterdam.
} 
luck? That I escaped quickly."90 In this example, Duikelaar's clumsiness is ridiculed in relation to the dirtiness of feet. References to smells, pain, and bodily excretions were intended humorously. Connecting failure and fraud was a typical comic device reappearing in many Dutch plays. ${ }^{91}$

In his next attempt, Duikelaar suffers from his own "inexperience": "Well, I thought what can be better than a peat carrier? To the first [client] I brought peat, two stairs high. I arrived at the highest threshold; I slipped and fell two stairs down. What was my luck? That it wasn't three stairs." (Duikelaar's name, which translates as "tumbler," also reflects clumsiness. Tumblers were artists who earned their living as clowns, making funny and clumsy gestures, and often tumbling on the stage.) Duikelaar then becomes a physician-and kills his patient with an ineffective medicine. In one of his last efforts at earning a living, he becomes a seller of mussels in cream at a fair. While the Jews do not buy from him (because the mussel is not kosher), "luckily" he is able to sell his merchandise, albeit at a loss..$^{92}$ The continuous failure to find profitable employment reflects the gallows humor of a people typically in economic despair. Humor became for them a means to cope psychologically with their hardships.

The Diskursn of the naye kille likewise draw a link between the inability to work in the crafts and the Jews' backwardness: "I want to serve this country in which I have a share. And for my household, too, by making a living in an honorable way. If you have a trade, buy yourself into a guild. If you have a shop that isn't free, buy yourself into a guild. Become a man. Don't remain a Jew in abjection." 93 Here, Dessauer presents manual labor as a cure for the wretched position of the Jews. Physical labor and its material result could turn them into citizens and human beings.

The negative representation of the Jews' methods of breadwinning was further fostered by their circular (or repeat) migration, a function of their ever-decreasing opportunities to settle and earn a living in Eastern Europe and the German-speaking countries. ${ }^{94}$ Some Jews even joined gangs, and in the eighteenth century some Dutch gangs were almost exclusively Jewish. ${ }^{95}$ This, coupled with a large group of betteljuden (Jewish beggars), added to the

\footnotetext{
${ }^{90}$ Antvert an Shloyme Duikelaar, YidNed 480, Library Rosenthaliana.

${ }^{91}$ B. A. M. Ramakers and Karel E. Eykman, eds., List en bedrog: Drie rederijkerskluchten (Amsterdam, 2009), 16-17.

${ }^{92}$ Antvert an Shloyme Duikelaar.

${ }^{93}$ Michman and Aptroot, eds. and trans., Storm in the Community, 136.

${ }^{94}$ For instance, Frederick II of Prussia issued a decree in 1744 restricting the settlement of Jews in Breslau, and in Russia Jews could reside only in the Pale of Settlement.

${ }^{95}$ Florike Egmond, Op het verkeerde pad: Georganiseerde misdaad in de Noordelijke Nederlanden, 1650-1800 (Amsterdam, 1994), 142-67.
} 
already negative image of the Jew. ${ }^{96}$ The bold image of the dishonorable Jew moving from city to city is embodied in two characters in the play Alz der sof iz gut, iz allez gut. One is Reb Yokesh, the wonder rabbi from Galicia, and the other is Yerushalmi, the swindler posing as a settlement collector. Both characters represent the wandering Eastern European Jewish immigrant. They do not have a craft but instead resort to preying on the goodness and naïveté of others. Reb Yokesh, for instance, is in search of a lucrative position as a teacher and extensively quotes rabbinic literature, which he quite often twists to his own benefit. Thus, when the host, the parnas Lipman, reacts suspiciously and questions his real intentions, Reb Yokesh changes the usual explanation of "let another man praise thee, but not thine own mouth" (Prov. 27:2) to the following: "Who is allowed to praise me? No more, no: it is written, let another man praise thee, that means a stranger, who does not know you; he is allowed to praise. From that it derives, if a man knows someone, that is to say someone like you, who no doubt knows me, he is not allowed to praise. Therefore, if a man fulfils this obligation, one does not praise. Also, I execute this rule and praise only myself." 97

Here, Reb Yokesh explains that, because one is not allowed to praise oneself, one also cannot be praised by an acquaintance. However, he then turns this explanation on its head, forgetting the first rule, namely, not to praise oneself. This bizarre explanation of the verse reveals the skill of the writer in playing with traditional Jewish texts and theological reasoning while at the same time criticizing those who use Jewish literature for their own gain. In a way, the play resembles the mid-nineteenth-century maskilic satire, condemning the Hasidic lifestyle and abuse of religious texts. As such, it is a good example of how Jewish unproductivity became a new theme in the Purim productions.

\section{Conclusion}

The Purim productions show an engagement with the Jewish Question, addressing such issues as productivity and the immense poverty of Dutch Jewry. Both poverty and unproductivity were criticized and positioned in relation to the occupational structure of Jewish society. The Purim's scatological and carnival traditions were used to channel political solutions to economic distress. Those solutions were not uncommon or new but instead reflected eighteenth-century ideas about the utility of mankind. In line with the thinking on utility, being useful was seen as the equivalent of being productive.

\footnotetext{
${ }^{96}$ Michman and Aptroot, eds. and trans., Storm in the Community, 136.

${ }^{97}$ Fuks, ed., All Is Well, 4.
} 
The crafts were hailed as honest occupations that could elevate the condition of Jews. Sometimes this critique was articulated explicitly, as in the case of Dessauer's songs, but more often it was implicit, through references to unemployment or shady professions. Intertwined with a critical stance toward the economic situation were stereotypical notions of Jewish poverty and unproductivity.

By mixing scatological humor, absurd situations, and weather conditions with political solutions to the Jewish Question, the genre of the Purim production placed itself firmly within the contemporary Dutch satiric tradition of mixing humor with political opinion. Moreover, the Purim productions are an outstanding example of how the maskilim employed a religious framework for their critique of the Jewish community and the rule of the parnasim. 